\title{
Testing the enemy release hypothesis in a native insect species with an expanding range
}

Julia J. Mlynarek

The enemy release hypothesis $(\mathrm{ERH})$ predicts that the spread of (invasive) species will be facilitated by release from their enemies as they occupy new areas. However, the ERH is rarely tested on native (non-invasive, long established) species with expanding or shifting ranges. I tested the ERH for a native damselfly (Enallagma clausum) whose range has recently expanded in western Canada, with respect to its water mite and gregarine parasites. Parasitism levels (prevalence and intensity) were also compared between $E$. clausum and a closely related species, Enallagma boreale, which has long been established in the study region and whose range is not shifting. A total of 1150 damselflies were collected at three 'old' sites for E. clausum in Saskatchewan, and three 'new' sites in Alberta. A little more than a quarter of the damselflies collected were parasitized with, on average, 18 water mite individuals, and 20\% were parasitized by, on average, 10 gregarine individuals. I assessed whether the differences between levels of infection (prevalence and intensity) were due to site type or host species. The ERH was not supported: Enallagma clausum has higher or the same levels of parasitism in new sites than old sites. However, $E$. boreale seems to be benefitting from the recent range expansion of a native, closely related species through ecological release from its parasites because the parasites may be choosing to infest the novel, potentially naïve, host instead of the well-established host. 
1 Testing the enemy release hypothesis in a native insect species with an

2 expanding range.

3 Julia J. Mlynarek ${ }^{1}$

$4 \quad{ }^{1}$ Biology Department, University of New Brunswick, Fredericton, New Brunswick, Canada

5 Corresponding Author:

6 Julia Mlynarek $^{1}$

7 Biology Department, University of New Brunswick, Fredericton, New Brunswick, Canada

8 Email address: Julia.mlynarek@gmail.com 


\section{ABSTRACT:}

10 The enemy release hypothesis (ERH) predicts that the spread of (invasive) species will be

11 facilitated by release from their enemies as they occupy new areas. However, the ERH is rarely

12 tested on native (non-invasive, long established) species with expanding or shifting ranges. I

13 tested the ERH for a native damselfly (Enallagma clausum) whose range has recently expanded

14 in western Canada, with respect to its water mite and gregarine parasites. Parasitism levels

15 (prevalence and intensity) were also compared between E. clausum and a closely related species,

16 Enallagma boreale, which has long been established in the study region and whose range is not

17 shifting. A total of 1150 damselflies were collected at three 'old' sites for E. clausum in

18 Saskatchewan, and three 'new' sites in Alberta. A little more than a quarter of the damselflies

19 collected were parasitized with, on average, 18 water mite individuals, and $20 \%$ were parasitized

20 by, on average, 10 gregarine individuals. I assessed whether the differences between levels of

21 infection (prevalence and intensity) were due to site type or host species. The ERH was not

22 supported: Enallagma clausum has higher or the same levels of parasitism in new sites (average

23 water mite and gregarine prevalence $38 \%$ and $20 \%$ respectively) than old sites (average water

24 mite and gregarine prevalence $6 \%$ and $7 \%$ respectively). Enallagma boreale has higher

25 parasitism rates at historically sympatric sites (average water mite and gregarine prevalence $40 \%$

26 and 30\%) then at new sympatric sites (average water mite and gregarine prevalence $18 \%$ and

$2722 \%$ respectively). So, E. boreale seems to be benefitting from the recent range expansion of a

28 native, closely related species through ecological release from its parasites because the parasites

29 may be choosing to infest the novel, potentially naïve, host instead of the well-established host. 
INTRODUCTION

32 habitat when its former enemies (e.g. parasites) are not present (Keane \& Crawley, 2002). This

33 hypothesis has been widely applied to invasive species, such as plant or animal pests in new

34 habitats (Colautti et al., 2004). There is mixed support for this hypothesis (Heger \& Jeschke,

35 2014). A review by Colautti et al. (2004) found that the ERH was supported in 11 of 13 such

36 studies. However, in comparisons of co-occurring evolutionarily related species, where one was

37 an established resident and the other a newcomer, the ERH was supported in only a third of the

38 studies. The reason for this lack of support for the ERH could be that the established species has

39 evolved defenses against the enemy whereas the new species is still naïve and susceptible

40 (Colautti et al., 2004). In other words, the invading species is joining a community that already

41 has a close relative to which enemies exist and so has enemies poised for potential attack on the

42 invader, as seen in Darwin's Naturalization Hypothesis (Darwin, 1859; Daehler, 2001) or the

43 Parasite Mediated Competition Hypothesis (Price, Westoby \& Rice, 1988).

44 Since the review of Colautti et al. (2004), the ERH has continued to be debated: the

45 hypothesis was not supported in bullfrogs (Dare \& Forbes, 2013) and gobies (Gobiidae) (Kvach 46 et al., 2014) or leafrollers (Totricidae) (Buergi \& Mills, 2014) but was demonstarted in ladybird

47 beetles (Coccinellidae) (Comont et al., 2014) and brine shrimp (Artemiidae) (Rode et al., 2013).

48 The ERH has been intensively studied with invasive species, particularly plants, where it has

49 more support (Liu \& Stiling, 2006). ERH has also been applied to host shifts (as enemy-free

50 space), where the release from enemies comes not from removal in space but through movement

51 to a species to a new host where enemies do not find that species (Heard et al., 2006). Other

52 hypotheses, such as the Evolution of Increased Competitive Ability Hypothesis, have been

53 proposed as alternatives. In this hypothesis, the invasive species evolve better competitive 
54 abilities than their close relatives over time (Blossey \& Notzold, 1995). In a meta-analysis, there

55 was little support for it (Felker-Quinn, Schweitzer \& Bailey, 2013). However, studies testing

56 these hypotheses have almost exclusively focused on invasive species.

57 Invasive species are not the only species whose ranges are changing; the ranges of native

58 species are not static and change with climate or changing landscapes (Chen et al., 2011, Burrows

59 et al., 2014). Shifts in species ranges can have consequences for species interactions, as a focal

60 species encounters new partners or enemies and leaves old ones behind. Of course, range shifts

61 can be caused by species interactions, as well; species can be pushed out of areas and into new

62 ones by competition and predation, or can colonize new areas as they follow the range shifts or

63 their own prey (Davis et al., 1998). However, there are few studies of species with shifting and

64 expanding ranges (other than recently introduced species) that test and show support for the ERH.

65 In a survey of common milkweed, Asclepias syriaca L. (Apocynaceae), natural populations at the

66 geographical extremes of the ranges showed less herbivory (e.g. leaf damage and insect diversity)

67 than those at the center of the range (Woods et al., 2012). Prior \& Hellman (2013) studied the

68 oak-gall forming wasp Neuroterus saltatorius Hartig (Cynipidae), whose range is expanding

69 northward, and found support for the ERH in both natural and experimental settings: the wasp

70 had greater demographic success and fewer parasitoids in the new range. The ERH was also

71 supported in a marine whelk, Kelletia kelletii (Forbes) (Buccinidae), with an expanding range

72 (Hopper et al., 2014); despite poorer demographic performance in the expanded range

73 populations, the whelk had only one fifth as many parasites as the historic-range populations.

74 I studied a native Nearctic damselfly, Enallagma clausum Morse (Odonata:

75 Coenagrionidae), whose range is expanding westward in Canada. I tested the ERH by comparing

76 prevalence and intensity of parasite infection in older, established populations of E. clausum (as a

77 baseline) to those in newly occupied sites. I also contrasted parasitism of E. clausum with that of 
78 close relative, Enallagma boreale Selys (Odonata: Coenagrionidae), which co-occurs at both the

79 old and new sites. Enallagma clausum is a widespread species in Manitoba, Saskatchewan, and

80 the northwestern United States (Walker, 1953), but has been moving westward into Alberta

81 through the parklands ecoregion in the past few decades (Acorn, 2004). The reasons for

82 expansion are unclear, but it is most likely due to increased availability of new habitat with

83 increased standing water in the prairies during the summertime due to recently built cattle

84 dugouts, irrigation canals, waterfowl projects, and power plants (Acorn, 2004). This westward

85 expansion is being documented in many Lepidoptera as well as other odonates (Acorn, pers.

86 comm.). Enallagma boreale is widespread throughout North America, its distribution reaching

87 the Yukon, and has been established in Alberta for over 100 years (Walker, 1953).

The most common parasites of damselflies are water mites (Arthropoda: Acari) and gregarines (Protozoan: Apicomplexa) (Corbet, 1999). Arrenurus water mites (Arrenuridae) are

90 external parasites of many insects associated with aquatic habitats (Smith, Cook \& Smith, 2010).

91 Arrenurus spp. are phoretically associated with the larval damselfly host; water mites attach

92 parasitically and start feeding only on adult damselflies (Smith, Cook \& Smith, 2010). Water

93 mites feed on their hosts until fully engorged, and then drop back into the water to continue their

94 life cycle. Gregarines, in contrast, are internal gut parasites of arthropods (Clopton, 2009).

95 Gregarines develop and mate in the host mid-gut and are released into the environment as cysts.

96 Gregarines are probably acquired from the environment; cysts have been observed on legs of

97 prey items (Åbro, 1976).

The main objective of this study was to test the ERH by observing whether E. clausum is as frequently attacked by external and internal parasites in the newly occupied sites as in the 'old'

100 sites where it has been long established. Secondarily, by observing E. boreale, I could determine

101 whether the arrival of E. clausum either dilutes the parasite pool and spares the well-established 
102 close relative (Brown, McPeek \& May, 2000), or increases the parasite pool and increases

103 parasitism on both host species. I could therefore determine if at 'new' sites there are parasite

104 populations that are locally adapted to their familiar host but not to the newly arriving one. If $E$.

105 clausum is released from its enemies, I expect this species would have lower measures of

106 parasitism in the new sites and there would not be a difference in parasitism in E. boreale

107 between old and new sites. However, if there is another pattern of infection, such as differences in

108 levels of parasitism in E. boreale or E. clausum not being freed from its parasites in the new sites,

109 parasite-mediated competition, one host species benefits indirectly from the presence of a second

110 related host species because the parasite has an alternate host (Price, Westoby \& Rice, 1988)

111 could be occurring.

\section{METHODS}

\section{Host and parasite sampling}

114 Adult hosts (Enallagma clausum and Enallgma boreale) were collected at six sites in the

115 parklands ecoregion of Canada (Fig. 1). Adults were collected because it is at the adult life

116 history stage that, both, successful water mite and gregarine parasitism can be assessed.

117 Lakes are all in the same ecozone, similar latitude and any other global parameters. They were

118 chosen because of their proximity, their environmental similarities, and because they provide

119 suitable habitat for Enallagma damselflies: all lakes are shallow, slightly saline, with sandy

120 bottoms and grassy vegetation along the edges. Three 'old' sites in Saskatchewan: Lenore Lake

121 (52 $\left.28^{\prime} 56.86^{\prime \prime} \mathrm{N}, 104^{\circ} 56^{\prime} 55.88^{\prime \prime} \mathrm{W}\right)$, Manitou Lake (52॰46'25.61"N, 10944'19.37"W), and

122 Redberry Lake $\left(52^{\circ} 41^{\prime} 30.30^{\prime \prime} \mathrm{N}, 107^{\circ} 10^{\prime} 17.71^{\prime \prime} \mathrm{W}\right)$, were chosen because both damselfly species

123 were known from these sites for at least 60 years (Walker, 1953). The old sites are an average

124 distance of 200 kilometers from each other. Three 'new' sites in Alberta: Gull Lake 


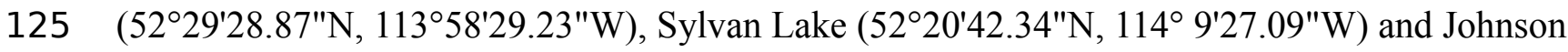

126 Lake $\left(50^{\circ} 35^{\prime} 44.60^{\prime \prime} \mathrm{N}, 111^{\circ} 53^{\prime} 27.09^{\prime \prime} \mathrm{W}\right)$, were selected based on E. clausum being first recorded

127 in this area in the last decade (Acorn 2004). Sylvan lake is 20 kilometers from Gull lake and 240

128 kilometers from Johnson lake. Although these lakes are similar ecologically, they range in size

129 from one $\mathrm{km}^{2}$ (Johnson Lake) to $80 \mathrm{~km}^{2}$ (Gull Lake. In addition, unlike all the other lakes,

130 Manitou is fishless. On a continental scale the lakes are close together, so there is the assumption

131 that host phenological and ecological differences between the sites are negligible. No collecting

132 permits were required for specimen collection.

133 Each site was visited twice in the first two weeks of July 2012, which is the documented

134 peak time of activity for these two host species and their associations with parasites (Walker,

135 1953; Mlynarek, Knee \& Forbes, 2014). During each site visit, 18 to 30 individuals of each

136 damselfly species were collected by aerial sweep net by a single collector walking through the

137 grass along the shoreline of the sites. Arrenurus spp. infection was tallied in the field. A total of

138497 E. clausum and 653 E. boreale hosts were examined for Arrenurus parasitism. Female

139 damselflies were omitted from analyses because of low sample size and the potential for sex bias

140 in parasitism (Forbes \& Robb, 2008). A random subset of the damselfly specimens (342 E.

141 boreale and 343 E. clausum) were collected and stored in separate vials in 95\% ethanol for

142 dissection in the lab to assess gregarine parasitism (see Table S1).

143 Water mites are usually located on either the ventral side of the thorax or the posterior

144 ventral portion of the abdomen (Smith, Cook \& Smith, 2010). All water mites were tallied and

145 treated as a single taxonomic unit to compare prevalence and intensity of parasitism (Corbet,

146 1999; Smith, Cook \& Smith, 2010) because the mites are largely generalist species that would be

147 expected to have similar host ranges (Mlynarek et al, 2015). 
149 membrane between the dorsal tergites and the ventral sclerites to expose the gut. Once the gut

150 was exposed the gregarine individuals could be tallied under 10x magnification. As with water

151 mites, all gregarines were combined as one taxonomic unit based on the assumption that

152 gregarines are generalists and are expected to infect evolutionary congeners. .

\section{Analyses}

154 Prevalence (proportion of infected individuals per site) and mean intensity (average number of

155 parasites per infected individual) were measured for each parasite group. Confidence intervals for

156 both measures were calculated using QP3.0 (Rózsa, Reiczigel \& Majoros, 2000).

157

Two-way ANOVAs were used to describe the direct and interactive effects of 'species'

158 and 'site type' ('old' vs. 'new') on the prevalence and intensity of parasitism by water mites and

159 gregarines. Four two-way ANOVAs were performed, one for each measure of parasitism and for

160 each parasite group. All analyses were performed in JMP v.11 (SAS 2013).

\section{RESULTS}

\section{Water mite parasitism}

164 Clopper-Pearson confidence interval) and 0.71 (0.58-0.82 95\% CI; Table 1). Intensity varied

165 between $12.8(3.07-31.1495 \%$ bootstrap CI) and 36.8 mites per infected host (19.8-50.7 95\%

166 bootstrap CI; Table 1). In E. boreale, prevalence varied between $0.11(0.06-0.1695 \% \mathrm{CI})$ and

$1670.65(0.49-0.7895 \%$ CI). Intensity varied between $8.05(5.27-12.695 \%$ bootstrap CI) and 27.9

168 (20.8-37.1 $95 \%$ bootstrap CI; Table 1). 
169 There were significant differences in Arrenurus prevalence in the species by site

170 interaction $\left(\mathrm{F}_{1,11}=22.2 ; \mathrm{P}<0.01\right.$; Table $\left.2 \mathrm{a}\right)$. Enallagma clausum had a significantly higher

171 prevalence of Arrenurus parasites at new sites than at old sites (Fig. 2a) whereas, Enallagma

172 boreale showed a higher prevalence of Arrenurus parasites at old sites (Fig. 2a). There was a

173 significant species $\mathrm{x}$ site type interaction for Arrenurus intensity as well $\left(\mathrm{F}_{1,11}=6.16 ; \mathrm{P}=0.02\right.$;

174 Table 2b). Again, intensity was higher for E. clausum at new sites then old sites, but lower at new

175 sites then old sites for E. boreale (Fig. 2b).

\section{Gregarine parasitism}

177 Gregarine prevalence in E. clausum varied between $0.01(0.00-0.0895 \% \mathrm{CI})$ and 0.41

$178(0.29-0.5495 \%$ CI; Table 1) over all the sites. Intensity varied between $3.50(2.00-3.5095 \%$

179 bootstrap CI) to 11.56 (7.80-16.48 95\% bootstrap CI; Table 1). In E. boreale, gregarine

180 prevalence varied between $0.09(0.03-0.1995 \% \mathrm{CI})$ and $0.48(0.34-0.6195 \% \mathrm{CI}$; Table 1$)$.

181 Intensity varied between 7.00 (2.00-13.50 95\% bootstrap CI) and 22.43 (7.00-46.14 95\%

182 bootstrap CI; Table 1).

183 There were non-significant differences in species by site type for gregarine prevalence

$184\left(\mathrm{~F}_{1,11}=3.68, \mathrm{P}=0.07\right.$; Table $\left.3 \mathrm{a}\right)$, or in species by site type for gregarine intensity $\left(\mathrm{F}_{1,11}=2.47\right.$,

$185 \mathrm{P}=0.13$; Table $3 \mathrm{~b}$ ). However, the gregarine prevalence was close to significant, paralleling the 186 patterm of Arrenurus mites where gregarine prevalence tended to be higher at new sites for $E$.

187 clausum and at old sites for E. boreale (Fig. 2c,d).

\section{DISCUSSION}

The Enemy Release Hypothesis (ERH) predicts that a species whose range is expanding

190 should have lower levels of parasitism in 'new' sites versus 'old' sites. In this case, E. clausum

191 had significantly higher prevalence and intensity of Arrenurus in 'new' sites than in 'old' sites. 
192 Gregarine prevalence was also greater in new sites compared to old sites, though only to a

193 marginally significant degree. There was no significant difference in gregarine intensity. Another

194 expectation of the ERH is that a recently colonized species should have lower levels of parasitism

195 than a long-time resident in the same new geographic area. This effect was not observed in either

196 measure of water mite or gregarine parasitism. Instead, there was significantly higher Arrenurus

197 parasitism in the newly occupied sites in E. clausum, the species whose range is expanding,

198 compared to both E. boreale and to E. clausum populations at old sites. There could be a

199 confounding effect with the pooling of species of each parasite group together to test ERH on the

200 prevalence and intensity of parasitism rather then on specific parasite identity. This pooling of

201 each parasite group into a morpho-group may mask what is happening at the species level. There

202 is a possibility that different species might adapt differently to different hosts, and may be at

203 different densities and thereby creating confounding problems when pooled. Because of the

204 issues with parasite identification, the aim of this study to test ERH on particular parasite species

205 but on the prevalence and intensity of morphogroups and could determine that there are clear

206 differences in levels of parasitism. I can conclude that the ERH does not describe the patterns of

207 either water mite or gregarine measures of parasitism (such as prevalence and intensity) on $E$.

208 clausum.

209 An alternative explanation for these results involves parasite-mediated competition, where

210 a host species benefits indirectly because of the presence of a new closely related host (Price,

211 Westoby \& Rice, 1988), or Darwin’s Naturalisation Hypothesis, where the new species will not

212 be at an evolutionary advantage because a close relative is already present in those habitats and

213 has enemies (Daehler, 2001). These two Enallagma host species are probably in competition

214 because they are closely related (Brown, McPeek \& May, 2000) and have similar ecological

215 habits. There are some behavioural differences; in Eastern North America E. boreale develops in 
216 fish and E. clausum in dragonfly habitats in Eastern North America (McPeek, 1990). In this

217 study, both species were collected in sympatry, so it can be assumes that as larvae they developed

218 in the same lake and were under the same pressures. Enallagma boreale may be better at evading

219 these populations of parasites because it has had more time to coevolve with them at the sites

220 than E. clausum. Enallagma clausum and E. boreale obviously share a close evolutionary history

221 (Brown, McPeek \& May, 2000) and can share parasites across sites (Mlynarek, Knee \& Forbes

222 2014a), but E. clausum does not share an ecological evolutionary history with the particular

223 parasite population at the new sites. The parasites have a naïve close relative to exploit (Maron \&

224 Vila, 2001) a pattern also observed in anolis lizards (Schall, 1992) and in oak herbivory, where

225 there is increased herbivory on non-native oak species in the presence of native close relatives

226 (Pearse \& Hipp, 2014).

227 Another alternative for the observed patterns in E. clausum may involve the range edge

228 effect. There are many contributing factors that limit the extent of a species range limit, one of

229 which is increased parasite rates (Sexton et al., 2009). For example, populations of Calopteryx

230 maculata at the northern edge of their Canadian range have higher levels of parasitism than those

231 closer to the center of their range (J. Mlynarek unpubl.). Additionally, Kaunisto \& Suhonen

232 (2013) suggested that host damselflies at the edges of their ranges are under higher environmental

233 stress, and therefore may be more susceptible to parasites and infections.

234 It is possible that E. clausum did undergo enemy release when it first arrived at the sites

235 but the parasites subsequently quickly evolved to include them as a host. In this context, they are

236 not supporting the Evolution of Increased Competitive Ability Hypothesis, either. However, a

237 decade is a short time period of time in an evolutionary context, considering that water mites and

238 damselflies tend to have univoltine life cycles in these areas (Smith, Cook \& Smith, 2010).

239 Enallagma clausum has recently expanded its range on a continent it has long occupied. It may, 
240 therefore, not be leaving its enemies behind, in the sense that the mites and gregarines from its

241 former geographic range may be only slightly different from those in its newly occupied range.

242 Over the course of the ever-changing post-Pleistocene environment, with changes in both climate

243 and the distribution of appropriate habitats, damselflies and their parasites have likely existed in a

244 continually shifting dynamic for millennia. Indeed, species that are expanding their range may

245 actually be under higher parasitism pressure in new sites, whereas those already present may

246 benefit from their arrival in the short term.

\section{ACKNOWLEDGMENTS}

248 I thank John Acorn and Naomi Cappuccino for insights into this project, and Terry Wheeler and

249 Stephen Heard for comments on an earlier draft. 
250 REFERENCES

251 Åbro A. 1976. Mode of gregarine infection in Zygoptera (Odonata). Zoologica Scripta 5:265252275.

253 Acorn J. 2004. Damselflies of Alberta flying neon toothpicks in the grass. Edmonton. University 254 of Alberta Press.

255 Blossey B \& Notzold R. 1995. Evolution of increased competitive ability in invasive

256 nonindigenous plants — a Hypothesis. Journal of Ecology 83:887-889.

257 Brown J, McPeek M \& May M. 2000. A phylogenetic perspective on habitat shifts and diversity 258 in the North American Enallagma damselflies. Systematic Biology 49:697-712.

259 Buergi LP, Mills NJ. 2014. Lack of enemy release for an invasive leafroller in California:

260 temporal patterns and influence of host plant origin. Biological Invasions 16:1021-1034.

261 Burrows MT, Schoeman DS, Richardson AJ, Molinos JG, Hoffmann A, Buckley LB, Moore PJ, 262 Brown CJ, Bruno JF, Duarte CM, Halpern BS, Hoegh-Guldberg O, Kappel CV, Kiessling W, 263 O'Connor MI, Pandolfi JM, Parmesan C, Sydeman W, Ferrier S, Williams KJ \& Poloczanska ES. 264 2014. Geographical limits to species-range shifts are suggested by climate velocity. Nature $265507: 492-495$.

266 Chen I, Hill JK, Ohlemueller R, Roy DB \& Thomas CD. 2011. Rapid range shifts of species 267 associated with high levels of climate warming. Science 333:1024-1026.

268 Clopton RE. 2009. Phylogenetic relationships, evolution, and systematic revision of the septate 269 gregarines (Apicomplexa: Eugregarinorida: Septatorina). Comparative Parasitology. 76:167270190.

271 Colautti R, Ricciardi A, Grigorovich I \& MacIsaac H. 2004. Is invasion success explained by the 272 enemy release hypothesis? Ecology Letters 7:721-733.

273 Comont RF, Purse BV, Phillips W, Kunin WE, Hanson M, Lewis OT, Harrington R, Shortall CR, 274 Rondoni G \& Roy HE. 2014. Escape from parasitism by the invasive alien ladybird, Harmonia 275 axyridis. Insect Conservation and Diversity 7:334-342.

276 Corbet PS. 1999. Dragonflies : behavior and ecology of Odonata. Ithaca: Comstock Publishing 277 Associates.

278 Daehler CC. 2001. Darwin's naturalization hypothesis revisited. American Naturalist 158:324279330. 
280 Dare OK \& Forbes MR. 2013. Do invasive bullfrogs in Victoria, British Columbia, Canada, show 281 evidence of parasite release? Journal of Helminthology 87:195-202.

282 Darwin C. 1859. On the origin of species by means of natural selection, or the preservation of 283 favoured races in the struggle for life. London. Murray publisher, London.

284 Davis AJ, Jenkinson LS, Lawton JH, Shorrocks B \& Wood S. 1998. Making mistakes when 285 predicting shifts in species range in response to global warming. Nature 391:783-786. DOI: $28610.1038 / 35842$.

287 Felker-Quinn E, Schweitzer JA \& Bailey JK. 2013. Meta-analysis reveals evolution in invasive 288 plant species but little support for Evolution of Increased Competitive Ability (EICA). Ecological 289 Evolution 3:739-751.

290 Forbes MR \& Robb T. 2008. Testing hypotheses about parasite-mediated selection using odonate 291 hosts. In: A. Cordóba-Aguilar, ed. Dragonflies and Damselflies: Model Organisms for

292 Ecological and Evolutionary Research. Oxford. Oxford University Press.

293 Forbes M, Muma K \& Smith B. 1999. Parasitism of Sympetrum dragonflies by Arrenurus planus 294 mites: maintenance of resistance particular to one species. International Journal of Parasitology 295 29:991-999.

296 Heard SB, Stireman JO, Nason JD, Cox GH, Kolacz CR \& Brown JM. 2006. On the elusiveness 297 of enemy-free space: spatial, temporal, and host-plant related variation in parasitoid attack rates 298 on three gallmakers of goldenrods. Oecologia 150:421-434.

299 Heger T \& Jeschke JM. 2014. The enemy release hypothesis as a hierarchy of hypotheses. Oikos 300 123:741-750.

301 Hopper JV, Kuris AM, Lorda J, Simmonds SE, White C \& Hechinger RF. 2014. Reduced parasite 302 diversity and abundance in a marine whelk in its expanded geographical range. Journal of 303 Biogeography 41:1674-1684.

304 Kaunisto KM \& Suhonen J. 2013. Parasite burden and the insect immune response:

305 interpopulation comparison. Parasitology 140:87-94.

306 Keane R \& Crawley M. 2002. Exotic plant invasions and the enemy release hypothesis. Trends in 307 Ecology and Evolution 17:164-170.

308 Kvach Y, Kornyychuk Y, Mierzejewska K, Rubtsova N, Yurakhno V, Grabowska J \& Ovcharenko 309 M. 2014. Parasitization of invasive gobiids in the eastern part of the Central trans-European 310 corridor of invasion of Ponto-Caspian hydrobionts. Parasitology Research 113:1605-1624. 
311 Liu H \& Stiling P. 2006. Testing the enemy release hypothesis: a review and meta-analysis.

312 Biological Invasions 8:1535-1545.

313 Maron JL \& Vila M. 2001. When do herbivores affect plant invasion? Evidence for the natural 314 enemies and biotic resistance hypotheses. Oikos 95:361-373.

315 McPeek MA 1990. Behavioral differences between Enallagma species (Odonata) influencing 316 differential vulnerability to predators. Ecology 71:1714-1726.

317 Mlynarek JJ, Knee W, Smith B \& Forbes MR. 2015. Regionally widespread parasitic water mites 318 have relatively broad host species ranges. Canadian Journal of Zoology DOI:10.1139/cjz-20153190077.

320 Mlynarek JJ, Knee W \& Forbes MR. 2014a. Host phenology, geographic range size and regional 321 occurrence explain interspecific variation in damselfly-water mite associations. Ecography

322 DOI:10.1111/ecog.00997.

323 Mlynarek JJ, Knee W \& Forbes MR. 2014b. Explaining susceptibility and resistance to a multi324 host parasite. Evolutionary Biology 41:115-122.

325 Pearse IS \& Hipp AL. 2014. Native plant diversity increases herbivory to non-natives.

326 Proceedings of the Royal Society B DOI:10.1098/rspb.2014.1841.

327 Price P, Westoby M \& Rice B. 1988. Parasite-mediated competition — some predictions and 328 tests. American Naturalist 131:544-555.

329 Prior KM \& Hellmann JJ. 2013. Does enemy loss cause release? A biogeographical comparison 330 of parasitoid effects on an introduced insect. Ecology 94:1015-1024.

331 Rode NO, Lievens EJP, Segard A, Flaven E, Jabbour-Zahab R \& Lenormand T. 2013. Cryptic 332 microsporidian parasites differentially affect invasive and native Artemia spp. International 333 Journal of Parasitology 43:795-803.

334 Rózsa L, Reiczigel J \& Majoros G. 2000. Quantifying parasites in samples of hosts. Journal of 335 Parasitology 86:228-232.

336 Schall JJ. 1992. Parasite-mediated competition in Anolis lizards. Oecologia 92:58-64.

337 Sexton JP, McIntyre PJ, Angert AL \& Rice KJ. 2009. Evolution and ecology of species range 338 limits. Annual Review of Ecology, Evolution and Systematics 40:415-436.

339 Smith I, Cook D \& Smith B. 2010. Water mites (Hydrachnidiae) and other arachnids. In J. Thorp 340 and A. Covich, eds. Ecology and Classification of North American Freshwater Invertebrates 3rd 341 edition. London, Academic Press. 
342 Walker EM. 1953. The Odonata of Canada and Alaska, volume 1. Toronton, University Press.

343 Woods EC, Hastings AP, Turley NE, Heard SB \& Agrawal AA. 2012. Adaptive geographical 344 clines in the growth and defense of a native plant. Ecological Monograph 82:149-168. 
345 Table 1: Prevalence and intensity of Arrenurus water mite and gregarines on Enallagma boreale

346 and Enallagma clausum from six sites in Eastern Alberta and Western Saskatchewan (see

347 supplemental Table S1 for raw data). Prevalence with Clopper Pearson 95\% confidence limits

348 and mean intensity with Bootstrap (BCa) 95\% confidence limits with 2000 replications.

\begin{tabular}{|c|c|c|c|c|c|c|c|c|}
\hline \multirow[t]{2}{*}{ Species } & \multirow{2}{*}{$\begin{array}{l}\text { Site } \\
\text { Type }\end{array}$} & \multirow[t]{2}{*}{ Site } & \multicolumn{3}{|c|}{ Arrenurus } & \multicolumn{3}{|c|}{ Gregarine } \\
\hline & & & $\mathrm{N}$ & Prevalence & Intensity & $\mathrm{N}$ & Prevalence & Intensity \\
\hline \multirow[t]{12}{*}{ E. boreale } & \multirow[t]{6}{*}{ Old } & \multirow[t]{2}{*}{ Lenore } & \multirow[t]{2}{*}{61} & 0.32 & 9.00 & \multirow[t]{2}{*}{51} & 0.36 & 10.59 \\
\hline & & & & $(0.24-0.49)$ & $(5.27-12.64)$ & & $(0.26-0.54)$ & $(6.05-21.20)$ \\
\hline & & \multirow[t]{2}{*}{ Manitou } & \multirow[t]{2}{*}{186} & 0.37 & 8.59 & \multirow[t]{2}{*}{69} & 0.31 & 11.80 \\
\hline & & & & $(0.31-0.46)$ & $(6.24-12.27)$ & & $(0.22-0.46)$ & $(8.26-18.48)$ \\
\hline & & \multirow[t]{2}{*}{ Redberry } & \multirow[t]{2}{*}{48} & 0.51 & 27.48 & \multirow[t]{2}{*}{43} & 0.22 & 9.67 \\
\hline & & & & $(0.49-0.78)$ & $(20.81-37.10)$ & & $(0.15-0.44)$ & $(4.83-16.50)$ \\
\hline & \multirow[t]{6}{*}{ New } & \multirow[t]{2}{*}{ Gull } & \multirow[t]{2}{*}{131} & 0.18 & 7.92 & \multirow[t]{2}{*}{65} & 0.09 & 7.00 \\
\hline & & & & $(0.11-0.25)$ & $(3.70-19.22)$ & & $(0.03-0.19)$ & $(2.00-13.50)$ \\
\hline & & \multirow[t]{2}{*}{ Johnson } & \multirow[t]{2}{*}{59} & 0.24 & 17.47 & \multirow[t]{2}{*}{59} & 0.45 & 9.79 \\
\hline & & & & $(0.14-0.37)$ & $(9.64-36.14)$ & & $(0.34-0.61)$ & $(5.96-14.93)$ \\
\hline & & \multirow[t]{2}{*}{ Sylvan } & \multirow[t]{2}{*}{168} & 0.11 & 22.42 & \multirow[t]{2}{*}{55} & 0.12 & 21.86 \\
\hline & & & & $(0.06-0.16)$ & $(14.72-41.78)$ & & $(0.05-0.24)$ & $(7.00-46.14)$ \\
\hline \multirow[t]{12}{*}{ E. clausum } & \multirow[t]{6}{*}{ Old } & \multirow[t]{2}{*}{ Lenore } & \multirow[t]{2}{*}{67} & 0.08 & 10.67 & \multirow[t]{2}{*}{48} & 0.09 & 9.00 \\
\hline & & & & $(0.01-0.13)$ & $(2.00-29.33)$ & & $(0.03-0.23)$ & $(3.60-17.00)$ \\
\hline & & \multirow[t]{2}{*}{ Manitou } & 38 & 0.06 & 16.67 & 37 & 0.08 & 2.25 \\
\hline & & & & $(0.01-0.18)$ & $(1.00-24.50)$ & & $(0.01-0.18)$ & $(2.00-4.50)$ \\
\hline & & Redberry & 174 & 0.05 & 38.45 & 70 & 0.03 & 17.50 \\
\hline & & & & $(0.02-0.10)$ & $(19.76-50.67)$ & & $(0.00-0.08)$ & $(\mathrm{N} / \mathrm{A})$ \\
\hline & New & Gull & 83 & 0.17 & 20.00 & 65 & 0.07 & 3.80 \\
\hline & & & & $(0.1-0.27)$ & $(3.07-31.14)$ & & $(0.02-0.15)$ & $(2.00-6.50)$ \\
\hline & & Johnson & 73 & 0.29 & 13.77 & 61 & 0.42 & 11.41 \\
\hline & & & & $(0.19-0.41)$ & $(7.96-23.19)$ & & $(0.29-0.54)$ & $(7.80-16.48)$ \\
\hline & & Sylvan & 62 & 0.67 & 26.98 & 62 & 0.11 & 5.38 \\
\hline & & & & $(0.58-0.82)$ & $(20.39-36.41)$ & & $(0.06-0.24)$ & $(2.88-9.50)$ \\
\hline
\end{tabular}


349 Table 2 - Results of two-way ANOVA testing for differences between host species and site (Old 350 vs New) for (a) Arrenurus prevalence and (b) Arrenurus intensity infections in Enallagma 351 clausum, a native species whose range is expanding in western Canada, and Enallagma boreale, a 352 closely related long-established species.

\begin{tabular}{lcccc}
\hline Source & df & SS & F & P \\
\hline (a) Prevalence & & & & \\
\hline Species & 1,11 & 0.05 & 1.93 & 0.18 \\
Site & 1,11 & 0 & 0.18 & 0.66 \\
Species*Site & 1,11 & 0.53 & 22.18 & $<\mathbf{0 . 0 1}$ \\
\hline (b) Intensity & & & & \\
\hline Species & 1,11 & 3.51 & 0.1 & 0.75 \\
Site & 1,11 & 8.42 & 0.25 & 0.62 \\
Species*Site & 1,11 & 209.8 & 6.16 & $\mathbf{0 . 0 2}$ \\
\hline
\end{tabular}


353 Table 3 - Results of two-way ANOVA testing for differences between host species and site (Old 354 vs New) for (a) gregarine prevalence and (b) gregarine intensity infections in Enallagma 355 clausum, a native species whose range is expanding in western Canada, and Enallagma boreale, a 356 closely related long-established species.

\begin{tabular}{lcccc}
\hline Source & df & SS & F & P \\
\hline (a) Prevalence & & & & \\
\hline Species & 1,11 & 0.12 & 5.89 & 0.03 \\
Site & 1,11 & 0 & 0.05 & 0.83 \\
Species*Site & 1,11 & 0.08 & 3.68 & 0.07 \\
\hline (b) Intensity & & & & \\
\hline Species & 1,11 & 23.1 & 7.41 & 0.01 \\
Site & 1,11 & 0.21 & 0.07 & 0.8 \\
Species*Site & 1,11 & 7.69 & 2.47 & 0.13 \\
\hline
\end{tabular}




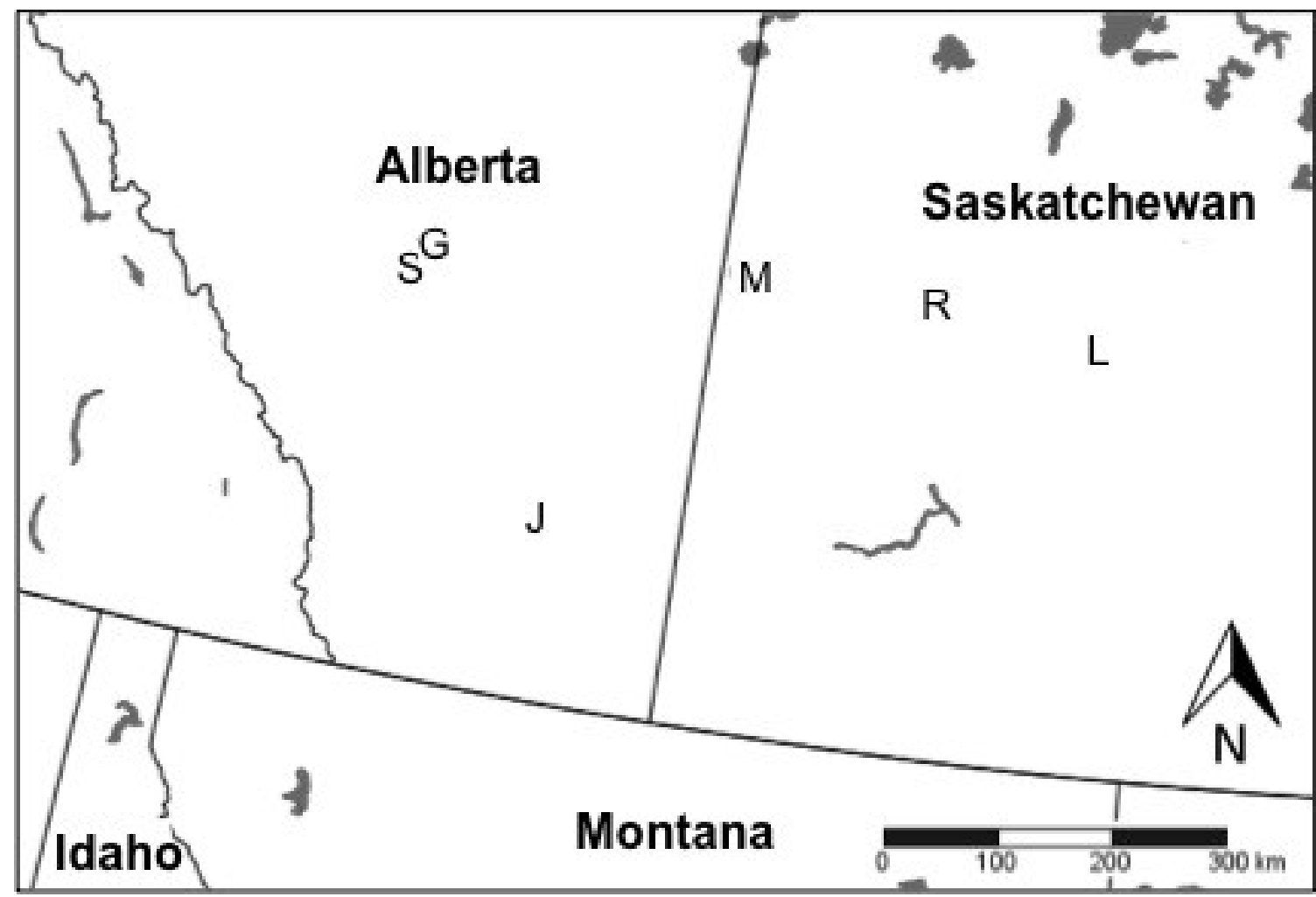

357 Figure 1: Map of study sites testing the enemy release hypothesis in the native species Enallagma 358 clausum in Saskatchewan and Alberta. Old sites: $\mathrm{L}=$ Lenore lake, $\mathrm{M}=$ Manitou lake, and $\mathrm{R}=$ 359 Redberry lake; New sites: $\mathrm{G}=$ Gull lake, $\mathrm{J}=$ Johnson lake, and $\mathrm{S}=$ Sylvan lake. 

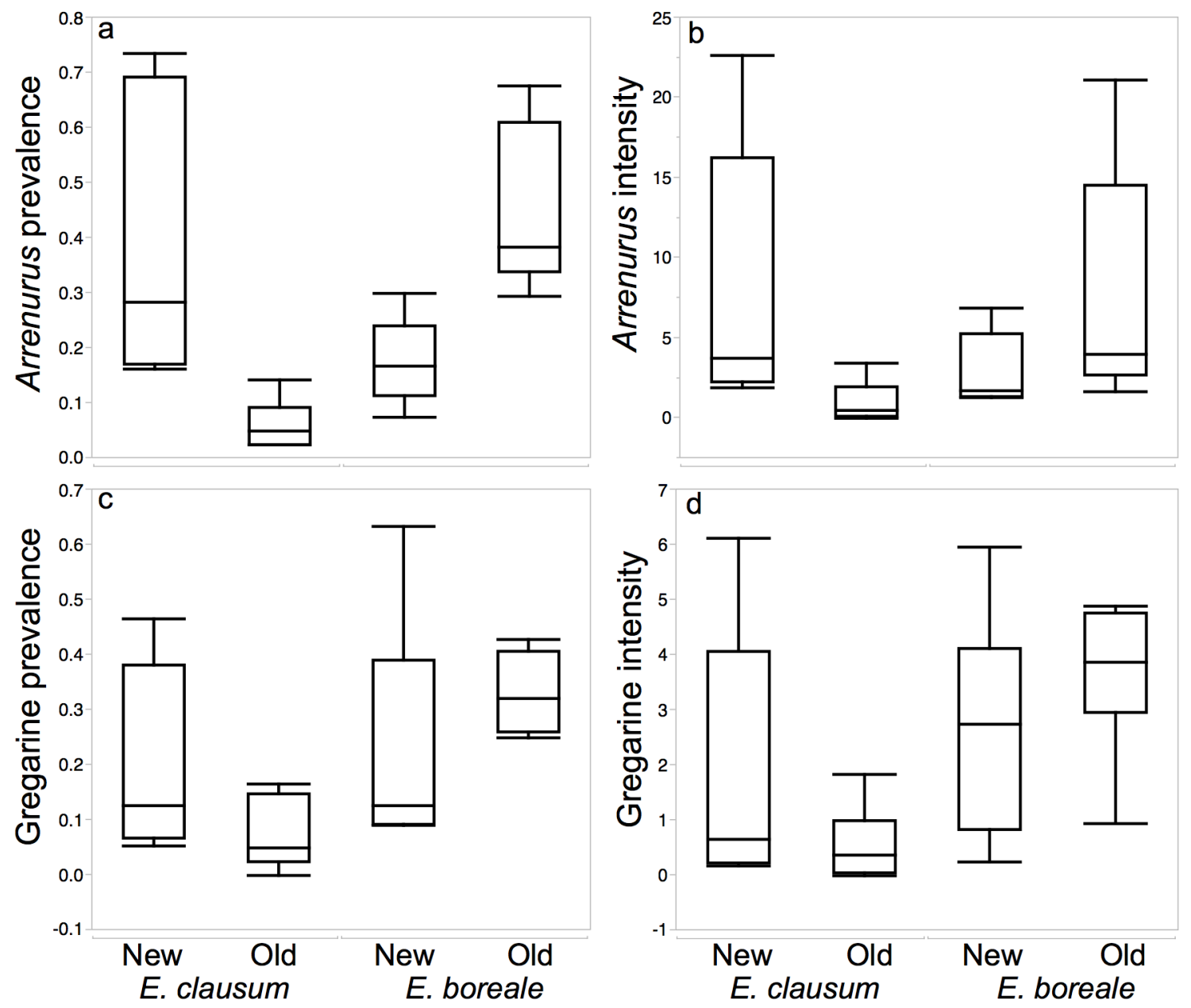

360 Figure 2: Boxplot of differences in (a) Arrenurus prevalence, (b) Arrenurus intensity, (c) 361 gregarine prevalence and (d) gregarine intensity between old and new sites for Enallagma 362 clausum, a native species whose range is expanding, and a closely related, well-established 363 species, Enallagma boreale. 


\section{Table $\mathbf{1}$ (on next page)}

Prevalence and intensity of Arrenurus water mite and gregarines on Enallagma boreale and Enallagma clausum from six sites in Eastern Alberta and Western Saskatchewan.

Table 1: Prevalence and intensity of Arrenurus water mite and gregarines on Enallagma boreale and Enallagma clausum from six sites in Eastern Alberta and Western Saskatchewan (see supplemental Table S1 for raw data). Prevalence with Clopper Pearson 95\% confidence limits and mean intensity with Bootstrap (BCa) 95\% confidence limits with 2000 replications. 
1 Table 1: Prevalence and intensity of Arrenurus water mite and gregarines on Enallagma boreale

2 and Enallagma clausum from six sites in Eastern Alberta and Western Saskatchewan (see

3 supplemental Table S1 for raw data). Prevalence with Clopper Pearson 95\% confidence limits

4 and mean intensity with Bootstrap (BCa) 95\% confidence limits with 2000 replications.

\begin{tabular}{|c|c|c|c|c|c|c|c|c|}
\hline \multirow[t]{2}{*}{ Species } & Site & \multirow[t]{2}{*}{ Site } & \multicolumn{3}{|c|}{ Arrenurus } & \multicolumn{3}{|c|}{ Gregarine } \\
\hline & Type & & $\mathrm{N}$ & Prevalence & Intensity & $\mathrm{N}$ & Prevalence & Intensity \\
\hline \multirow[t]{8}{*}{ E. boreale } & Old & Lenore & 61 & $\begin{array}{c}0.32 \\
(0.24-0.49)\end{array}$ & $\begin{array}{c}9.00 \\
(5.27-12.64)\end{array}$ & 51 & $\begin{array}{c}0.36 \\
(0.26-0.54)\end{array}$ & $\begin{array}{c}10.59 \\
(6.05-21.20)\end{array}$ \\
\hline & & Manitou & 186 & $\begin{array}{c}0.37 \\
031-046)\end{array}$ & $\begin{array}{c}8.59 \\
(624-1227)\end{array}$ & 69 & $\begin{array}{c}0.31 \\
(02-046)\end{array}$ & $\begin{array}{c}11.80 \\
(826-1848)\end{array}$ \\
\hline & & Redberry & 48 & 0.51 & 27.48 & 43 & 0.22 & $\begin{array}{c}9.67 \\
(483-1650)\end{array}$ \\
\hline & New & Gull & 131 & $\frac{(0.49-0.78)}{0.18}$ & $\frac{(20.81-37.10)}{7.92}$ & 65 & $\frac{0.15-0.44)}{0.09}$ & $\frac{(4.83-16.50)}{700}$ \\
\hline & & & & $(0.11-0.25)$ & $(3.70-19.22)$ & & $(0.03-0.19)$ & $(2.00-13.50)$ \\
\hline & & Johnson & 59 & 0.24 & 17.47 & 59 & 0.45 & 9.79 \\
\hline & & & & $(0.14-0.37)$ & $(9.64-36.14)$ & & $(0.34-0.61)$ & $(5.96-14.93)$ \\
\hline & & Sylvan & 168 & $\begin{array}{c}0.11 \\
(0.06-0.16) \\
\end{array}$ & $\begin{array}{c}22.42 \\
(14.72-41.78)\end{array}$ & 55 & $\begin{array}{c}0.12 \\
(0.05-0.24)\end{array}$ & $\begin{array}{c}21.86 \\
(7.00-46.14)\end{array}$ \\
\hline \multirow[t]{10}{*}{ E. clausum } & Old & Lenore & 67 & $\begin{array}{c}0.08 \\
(0.01-0.13)\end{array}$ & $\begin{array}{c}10.67 \\
(2.00-29.33)\end{array}$ & 48 & $\begin{array}{c}0.09 \\
(0.03-0.23)\end{array}$ & $\begin{array}{c}9.00 \\
(3.60-17.00)\end{array}$ \\
\hline & & Manitou & 38 & 0.06 & 16.67 & 37 & 0.08 & 2.25 \\
\hline & & & & $(0.01-0.18)$ & $(1.00-24.50)$ & & $(0.01-0.18)$ & $(2.00-4.50)$ \\
\hline & & Redberry & 174 & 0.05 & 38.45 & 70 & 0.03 & 17.50 \\
\hline & & & & $(0.02-0.10)$ & $(19.76-50.67)$ & & $(0.00-0.08)$ & $(\mathrm{N} / \mathrm{A})$ \\
\hline & New & Gull & 83 & $\begin{array}{c}0.17 \\
(0.1-0.27)\end{array}$ & $\begin{array}{c}20.00 \\
(3.07-31.14)\end{array}$ & 65 & $\begin{array}{c}0.07 \\
(0.02-0.15)\end{array}$ & $\begin{array}{c}3.80 \\
(2.00-6.50)\end{array}$ \\
\hline & & Johnson & 73 & 0.29 & 13.77 & 61 & 0.42 & 11.41 \\
\hline & & & & $(0.19-0.41)$ & $(7.96-23.19)$ & & $(0.29-0.54)$ & $(7.80-16.48)$ \\
\hline & & Sylvan & 62 & 0.67 & 26.98 & 62 & 0.11 & 5.38 \\
\hline & & & & $(0.58-0.82)$ & $(20.39-36.41)$ & & $(0.06-0.24)$ & $(2.88-9.50)$ \\
\hline
\end{tabular}




\section{Table 2 (on next page)}

Results of two-way ANOVA testing for differences between host species and site (Old vs New) for Arrenurus prevalence and intensity.

Table 2 - Results of two-way ANOVA testing for differences between host species and site (Old vs New) for (a) Arrenurus prevalence and (b) Arrenurus intensity infections in Enallagma clausum, a native species whose range is expanding in western Canada, and Enallagma boreale, a closely related long-established species. 
1 Table 2 - Results of two-way ANOVA testing for differences between host species and site (Old

2 vs New) for (a) Arrenurus prevalence and (b) Arrenurus intensity infections in Enallagma

3 clausum, a native species whose range is expanding in western Canada, and Enallagma boreale, 4 a closely related long-established species.

\begin{tabular}{lcccc}
\hline Source & df & SS & F & P \\
\hline (a) Prevalence & & & & \\
\hline Species & 1,11 & 0.05 & 1.93 & 0.18 \\
Site & 1,11 & 0 & 0.18 & 0.66 \\
Species*Site & 1,11 & 0.53 & 22.18 & $<\mathbf{0 . 0 1}$ \\
\hline (b) Intensity & & & & \\
\hline Species & 1,11 & 3.51 & 0.1 & 0.75 \\
Site & 1,11 & 8.42 & 0.25 & 0.62 \\
Species*Site & 1,11 & 209.8 & 6.16 & $\mathbf{0 . 0 2}$ \\
\hline
\end{tabular}

5 


\section{Table 3 (on next page)}

Results of two-way ANOVA testing for differences between host species and site (Old vs New) for gregarine prevalence and intensity

Table 3 - Results of two-way ANOVA testing for differences between host species and site (Old vs New) for (a) gregarine prevalence and (b) gregarine intensity infections in Enallagma clausum, a native species whose range is expanding in western Canada, and Enallagma boreale, a closely related long-established species. 
1 Table 3 - Results of two-way ANOVA testing for differences between host species and site (Old 2 vs New) for (a) gregarine prevalence and (b) gregarine intensity infections in Enallagma

3 clausum, a native species whose range is expanding in western Canada, and Enallagma boreale, 4 a closely related long-established species.

\begin{tabular}{lcccc}
\hline Source & $\mathrm{df}$ & $\mathrm{SS}$ & $\mathrm{F}$ & $\mathrm{P}$ \\
\hline (a) Prevalence & & & & \\
\hline Species & 1,11 & 0.12 & 5.89 & 0.03 \\
Site & 1,11 & 0 & 0.05 & 0.83 \\
Species*Site & 1,11 & 0.08 & 3.68 & 0.07 \\
\hline (b) Intensity & & & & \\
\hline Species & 1,11 & 23.1 & 7.41 & 0.01 \\
Site & 1,11 & 0.21 & 0.07 & 0.8 \\
Species*Site & 1,11 & 7.69 & 2.47 & 0.13 \\
\hline
\end{tabular}

5 


\section{Figure 1 (on next page)}

Map of study sites testing the Enemy Release Hypothesis in a native species with an expanding range.

Figure 1: Map of study sites testing the enemy release hypothesis in the native species Enallagma clausum in Saskatchewan and Alberta. Old sites: $L=$ Lenore lake, $M=$ Manitou lake, and R = Redberry lake; New sites: $\mathrm{G}=$ Gull lake, $\mathrm{J}=$ Johnson lake, and $\mathrm{S}=$ Sylvan lake. 


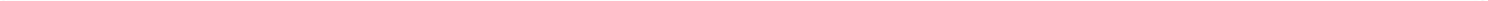


Figure 2 (on next page)

Boxplots demonstrating differences in measures of parasitism between host species and sites types while testing for the Enemy Release Hypothesis in a native damselfly species with an expanding range.

Figure 2: Boxplot of differences in (a) Arrenurus prevalence, (b) Arrenurus intensity, (c) gregarine prevalence and (d) gregarine intensity between old and new sites for Enallagma clausum, a native species whose range is expanding, and a closely related, well-established species, Enallagma boreale. 
